\title{
THE INFLUENCE OF PROFITABILITY AND ACTIVITY ON FINANCIAL PERFORMANCE IN MINING COMPANIES REGISTERED IN INDONESIA STOCK EXCHANGE
}

\author{
${ }^{123}$ Susiowati, Sochib, Muhamad Ali \\ Departement of Accountinng, STIE Widya Gama Lumajang ${ }^{12}$ \\ Universitas Hamzanwadi Lombok Timur ${ }^{3}$ \\ Email: shuzhy92@gmail.com
}

\section{A R T I C L E I N F O}

Date of entry:

15 Januari 2020

Revision Date:

17 February 2020

Date Received:

6 June 2020

\begin{abstract}
A B S T R A C T
This research was conducted with the aim to determine the effect of profitability and activity on financial performance in mining companies listed on the Indonesian stock exchange. Financial Performance is an illustration to find out the financial situation in a company for a certain period and analyzed with financial analysis tools. In assessing the financial performance of a company, it can use certain benchmarks. And usually the ratio is used. In this study, the calculation system used by researchers is to use profitability analysis tools (Net Profit Margin), activity (Inventory Turn Over) and performance (Return On Assets). The method used in this research is quantitative descriptive obtained by 17 samples of mining companies listed on the Indonesia Stock Exchange in the 2014-2017 period. Statistical test results in this study indicate that profitability variables have a significant positive effect on financial performance. But it is inversely related to activities that have no effect on financial performance.
\end{abstract}

Keywords: Profitability, Activity and Financial Performance

Cite this as: Susiowati., Liyundira, Fetri Setyo. (2020). THE INFLUENCE OF PROFITABILITY AND ACTIVITY ON FINANCIAL PERFORMANCE IN MINING COMPANIES REGISTERED IN INDONESIA STOCK EXCHANGE.. Assets : Jurnal Ilmiah Ilmu Akuntansi, Keuangan dan Pajak, 4(2), 83-88.

\section{INTRODUCTION}

Financial performance is an illustration to determine the financial condition of a company for a certain period and is analyzed using financial analysis tools. Cashmere (2014: 2). In assessing the financial performance of a company, certain benchmarks can be used. And usually used is the ratio. With this aim to get the final result or the maximum profit according to the target of the company, and to find out the level of profit or profit of a company, can make calculations using the profitability ratio or profit ratio.

And besides that, to find out or measure the length of time to collect accounts receivable for one period and the average collection of accounts payable, companies usually use one of the tools in conducting the evaluation, namely the Financial Activity Ratio. And this ratio is used by companies to analyze company performance and for taking decisions related to the analysis carried out. In order for this goal to be achieved, the company management must be able to make proper 
and accurate planning. Then so that the progress of the business being carried out can be monitored, each company must be able to make notes, books and reports on all of its business activities. These records, reports and books are made within a certain period in the form of financial reports.

Financial analysis that can be used is financial ratios such as profitability ratios and activity ratios. Hery, Financial Statement Analysis, (Jakarta: Gramedia Widiasarana Indonesia, 2016) page 192. According to Jumingan (2006: 239), financial performance is a description of the company's financial condition in a certain period whether it concerns the aspects of raising funds or distributing funds, and is usually measured using indicators of capital adequacy, liquidity, and profitability. According to Mutia Raisa Nasution (2008) in his journal writing financial performance measurements carried out simultaneously with the analysis process. and used as a measure or certain benchmarks. Mutia Raisa Nasution (2008). According to Kasmir (2014: 115) the profitability ratio is a ratio to assess a company's ability to seek profit. This ratio also provides a measure of the level of management effectiveness of a company. And this is shown by the profit generated from sales and investment income. In essence, this ratio shows the efficiency of the company.

The measurement of profitability ratios can be done by comparing the various components in the income statement and balance sheet. And this measurement can be done for several periods and aims to monitor and evaluate the level of development of the company's profitability over time. By comparing the financial ratio figures with the set numbers., then there will be other benefits, namely whether in certain financial aspects the company is above standard or below standard. If the company is below standard, then management will look for the factors that cause it to then take financial policies to increase the company's ratio again. According to cashmere (2014), the activity ratio is the ratio used by companies to measure the effectiveness of the company in using its assets. The use of the desired ratio depends on the desire of the company management (Kasmir, 2014). This means that whether the ratio of activities to be used is complete or not depends on the needs and goals the management of the company wants to achieve.

According to Sutrisno (2009: 53), financial performance is an achievement that the company has achieved in a certain period as a reflection of the company's health level. The company's financial performance is closely related to measurement and performance assessment. Performance measurement (performing measure) is the qualification \& efficiency and effectiveness of the company in operating the company's business during the accounting period. The performance appraisal according to Srimindarti (2006: 34) is the determination of operational and organizational effectiveness as well as employees based on the targets, standards and criteria that have been previously set periodically.

\section{METHODS}

In this study, researchers used a quantitative descriptive approach by calculating data in the form of financial reports. The methods used were collecting, classifying, analyzing then interpreting data and making conclusions. In this study, the type of data used by researchers is secondary data collected by data collection agencies and published to the general public. This secondary data is in the form of published financial reports of mining companies listed on the Indonesian Stock Exchange (IDX). The source of data used in this study is through the IDX (Indonesian Stock Exchange) which is the official website of the Indonesia Stock Exchange (IDX) http: / /idx.co.id/. The population in this study were all financial data of mining companies listed on the Indonesian Stock Exchange, during 2014-2017, as many as 51 companies and the sample in this study was 68 companies listed on the Indonesian Stock Exchange.

\section{RESULTS AND DISCUSSION}




\section{Statistik Deskriptif}

\begin{tabular}{|l|r|r|r|r|r|}
\hline & \multicolumn{1}{|c|}{ N } & \multicolumn{1}{|c|}{ Minimum } & \multicolumn{1}{c|}{ Maximum } & \multicolumn{1}{c|}{ Mean } & \multicolumn{1}{c|}{ Std. Deviation } \\
\hline ROA & 68 & 0,02 & 31,75 & 8,2187 & 8,49222 \\
\hline NPM & 68 & 0,04 & 25,45 & 8,5797 & 5,97089 \\
\hline ITO & 68 & 0,84 & 187,73 & 28.4628 & 37,48729 \\
\hline
\end{tabular}

Sumber: SPSS, Data processed by researchers 2020

\section{Profitability}

Based on the descriptive test in the table above, it can be seen that the highest (maximum) Net Profit Margin (NPM) value is 25.45 owned by PT. Surya Esa Perkasa Tbk (ESSA) in 2014, while the lowest (minimum) NPM value was 0.04 owned by PT. Darma Henwa Tbk (DEWA) in 2014. The results of this study indicate that the amount of Net Profit Margin (NPM) which is the sample of this study ranges from 25.45 to 0.04 with an average (mean) of 8.5797 and standard deviation amounting to 5,97089 .

\section{Activities}

The descriptive test results in the table above show that the highest ITO (Inventory Turn Over) value (maximum) 187.73 owned by Radiant Utama Interinsco (RUIS) in 2016, while the lowest (minimum) ITO (Inventory Turn Over) value was 0,84 which is owned by PT. Citatah (CTTH) in 2017. The results of this study indicate that the amount of ITO (Inventory Turn Over) which was the sample of this study ranged from 187.73 to 0.84 with an average (mean) of 28.4628 and a standard deviation of 37.48729 .

\section{Performance}

The descriptive test results in the table above show that the highest Return On Asset (ROA) value (maximum) was 31.75 owned by Mitrabara Adi Perdana Tbk (MBAP) in 2015, while the lowest Return On Asset (ROA) value (minimum) was 0,02 owned by PT. Surya Esa Perkasa Tbk (ESSA) and PT. Darma Henwa Tbk (DEWA) in 2014 and 2016. The results of this study indicate that the amount of Return On Asset (ROA) which is the sample of this study ranges from 31.75 to 0.02 with an average (mean) of 8.2187 and the standard deviation of 8.49222 .

\section{Classic assumption test}

Normality test

Ghozali (2016: 154) the normality test aims to test whether in the regression model, confounding or residual variables have a normal distribution. It is known that the $\mathrm{t}$ and $\mathrm{F}$ tests assume that the residual value follows a normal distribution. In this study, researchers used the One-Sample Kolmogorov-Smirnov Test method. The provisions of this test, namely if the sig value is greater than 5\%, it can be concluded that the residual spreads normally and if the sig is less than 5\% it can be concluded that the residual spread is not normal. Based on the result of Kolmogorov Smirnov, the Asym value. Sig. (2-tailed) of 240, the residuals spread normally because the sig value is more than 0.05 .

\section{Multicolonierity Test}

Multicolonierity can also be seen from (1) the tolerance value and its counterpart (2) variance inflation factor (VIF). These two measures indicate which independent variable is explained by the other independent variables. Tolerance measures the variability of the selected independent variable that is not explained by other independent variables. So a low tolerance value is the same as a high VIF value (because VIF $=1 /$ Tolerance). The cutoff value commonly used to indicate multicolonierity is the Tolerance value $\leq 0.10$ or equal to the VIF value $\geq 10$. Each researcher must determine the level of colonieritas that can be tolerated. The Tolerance value of the Profitability variable (NPM) and the Activity variable (ITO) was 0.982. From the results of each Tolerance 
value, it shows that the Tolerance value is more than 0.10 , which means that there is no multicollinearity. Meanwhile, the VIF value of the Profitability (NPM) and Activities (ITO) variable was 1.018. Each VIF value is smaller than 10, thus indicating that there are no symptoms of multicolonierity.

Autocorrelation Test

The result of this test shows that the Durbin Watson (DW) value is 1.950 . By looking at the watson durbin table, the DL value is 1.4853 while the value (4-DU) is 2.3322 which is obtained from $4-1.6678=2.3322$ while the DU is 1.7335 . If put into the formulation DU $<\mathrm{DW}<(4-\mathrm{DU})$ the result is $1.7335<1.950<2.3322$. Thus, the data used does not have autocorrelation problems.

\section{Heteroscedatisity Test}

From the Park test results show the sig of the profitability variable (NPM) of 0.000 and the activity variable (ITO) of 0.432 . Each variable sig is less than 0.05 , so in this study heteroscedasticity occurs.

Based on the table above, the following equation can be formed:

Information:

$$
\mathrm{Y}=-1.366+(1.067) \mathrm{X} 1+(0.015) \mathrm{X} 2
$$

$$
\begin{aligned}
& \mathrm{Y}=\text { Financial performance }(\mathrm{ROA}) \\
& \mathrm{X} 1=\text { Profitability }(\mathrm{NPM}) \\
& \mathrm{X} 2=\text { Activities (ITO) }
\end{aligned}
$$

The results of the calculation with this regression model produce an R square (R2) value of 0.554 , which means that the dependent variable of financial performance can be explained by the independent variables of profitability and activity by $55.4 \%$ and the rest is explained by other variables of $44.6 \%$ which are influenced by factors. others who are not included in the regression model

Partial test ( $\mathrm{t}$ test) is used to test the significance of the effect of the independent variable (profitability and activity) on the dependent variable (financial performance). The criterion used in decision making is that $\mathrm{H}$ is accepted if Sig $\mathrm{t}<$ significant level a (0.005).

1. Based on the test results above, on the independent variable profitability (NPM) the significance value is $<0.05$, namely 0.00 . Which means that $\mathrm{H} 1$ is acceptable and profitability has a significant effect on financial performance.

2. Based on the test results above, the activity independent variable (ITO) has a significance value> 0.05 , namely 0.432 . Which means that $\mathrm{H} 2$ is unacceptable and activity has no significant effect on financial performance.

The $\mathrm{F}$ test is used to test whether the regression model is feasible or fit. Trust is significant at $5 \%$ or 0.05 , if $\mathrm{F}$ count is greater than $\mathrm{F}$ table then all independent variables simultaneously affect the dependent variable. Based on the results of the simultaneous test, the calculated F value is 40.422 with a significance of 0.000 . The significance value is less than 0.05 , which is equal to 0.000 , so it can be concluded that the independent variable has a simultaneous effect on the dependent variable.

\section{Discussion}

Effect of Profitability on Financial Performance

The results of hypothesis testing indicate that profitability has a significant effect on financial performance as shown in Table 4.12. The results of this study mean that when the Net Profit Margin (NPM) in mining companies for the 2014-2017 period has increased, the financial performance will increase and vice versa, if the NPM has decreased, the financial performance will decrease. This shows that profitability is directly proportional to financial performance. In this study, the results of observations made at mining companies for the 2014-2017 period showed that 
the profitability ratio as measured by using the Net Profit Margin experienced a significant increase with a percentage of $61.8 \%$. With a high profitability ratio, it shows that the company has achieved success by getting high profits so that the company's performance will be even higher. This will convince potential investors to give their capital to the company. The relationship between profitability and financial performance is positive and significant, which means that the higher the profitability ratio, the higher the financial performance.

This research is in line with Eka Indriyani (2017) and Sutama \& Lisa (2018) which state that profitability has a significant positive effect on financial performance, which means that the higher profitability, the changes in financial performance will increase. However, this study contradicts the research conducted by Kurniawati et al. (2018) and Khoirun Nur Khasanah (2017) which show that profitability has no effect on financial performance.

Effect of Activities on Financial Performance

The results of hypothesis testing indicate that Inventory Turn Over has no significant effect on financial performance (ROA). In this study the results of observations (observations) made at mining companies for the period 2014-2017, the ratio of activities measured using Inventory Turn Over was $0.82 \%$. This means that the higher the inventory turnover rate, the lower the financial performance of a company is. Return on assets has no relationship with financial performance (ROA) which is indicated by the absence of activity influence on financial performance, which states that the higher the Inventory Turn Over, the lower the financial performance will be. The absence of this effect indicates that the size of Inventory Turn Over cannot describe and predict an increase in return on assets. To increase the company's return on assets, what can be done is to increase sales and reduce the expenses incurred by the company and the company will get a large profit and the return on assets will also increase (Budiang et al., 2017).

This research is in line with Intan Eprilia and Lestari Siregar (2020) which states that activity does not affect financial performance, which means that the higher the turnover rate of goods, the lower the financial performance. However, this research contradicts Subarjo and Fitri Wulan Sari (2017) which state that activities have an effect on financial performance

\section{CONCLUSION}

Based on the results of the analysis carried out in this study, the following conclusions can be drawn: In the analysis of profitability ratios in mining companies, seen from the average Net Profit Margin (NPM), it can be concluded that mining companies have a significant positive effect on financial performance, which means that the higher the profitability ratio, the higher the financial performance. With a high profitability ratio, it shows that the company has achieved success by getting high profits so that the company's performance will be even higher. This will convince potential investors to give their capital to the company. In the analysis of the activity ratios of mining companies as seen from the average Inventory Turn Over (ITO) it can be concluded that mining companies do not have a significant effect on financial performance (ROA). Return on assets has no relationship with financial performance (ROA) which is indicated by the absence of activity influence on financial performance. The absence of this effect indicates that the size of Inventory Turn Over cannot describe and predict an increase in return on assets.

\section{REFERENCE}

Fahmi, Riza Nur. 2013.Pengaruh Rasio Likuiditas Dan Rasio AktivitasTerhadapPerubahanLaba Pada Perusahaan PertambanganYang Terdaftar Di Bursa Efek Indonesia (Bei) Periode 2009-2011. Yogyakarta:Universitas Negeri Yogyakarta.

Trianto,Anton.2017. Analisis Laporan Keuangan Sebagai Alat Untuk Menilai Kinerja Keuangan Perusahaan Pada PT. Bukit Asam (Persero) Tbk Tanjung Enim. Jurnal,Program Studi 
Akuntansi Politekhnik Darussalam Vol. 8 No. 03 Desember 2017 ISSN: 20892502.Palembang.

Khasanah,Khoirun Nur.2017. Analisis Rasio Profitabilitas dan Rasio Likuiditas Untuk Menilai Kinerja Keuangan PT.Mayora Indah,Tbk Tahun 2010-2015.Jurnal, SimkiEconomic Vol. 012017 ISSN: BBBB-BBBB. Kediri.

Nasutiuon,Mutia Raisa,2018. Analisis Rasio Profitabilitas Sebagai Alat Untuk Menilai Kinerja Keuangan Pada PT.Jayawi Solusi. Medan: Universitas Islam Negri Sumatra Utara Medan.

Kasmir. (2016). Analisis Laporan Keuangan. Jakarta: PT RajaGrafindo Persada.

Paramita, R. W. D., \& Rizal, N. (2019). Metode Penelitian Kuantitatif. Yogyakarta: Azyan Mitra Media.

Ghozali, I. (2016). Aplikasi Analisis Multivariete dengan Program IBM SPSS 23. Semarang: Badan Penerbit Universitas Diponegoro.

Nurhasanah, S. (2016). Pratikum Statistika 2 untuk Ekonomi dan Bisnis Aplikasi dengan Ms Excel dan SPSS. Jakarta: Salemba Empat.

Budiang, F.T., Pangemanan, S. S., \& Gerungai, N. Y. T. 2017. Pengaruh Perputaran Total Asset, Perputaran Piutang dan Perputaran Persediaan Terhadap ROA pada Perusahaan Sub Sektor Perdagangan Eceran yang Terdaftar di BEI.EMBA, 5(2), 1956-1966.

Kasmir, Analisis Laporan Keuangan,Jakarta: Rajawali Pers,2014

Fahmi, Irham.,Analisis Kinerja Keuangan , Bandung : Alfabeta,2017 